\title{
Disease Incidence and Symptoms of White Rot of Onion caused by Sclerotium rolfsii in Manipur
}

\author{
Rimamay Konjengbam*, Rajkumari Tombisana Devi and Naorem Iboton Singh
}

Central Agricultural University, Imphal, Manipur, India

*Corresponding author

\section{A B S T R A C T}

Keywords

Onion, White rot, Sclerotium rolfsii, Disease incidence, Sclerotia

\section{Article Info}

Accepted: 04 December 2020 Available Online: 10 January 2021
Onion (Allium cepa L.) is an important vegetable and spice crop in Manipur. White rot of onion caused by Sclerotium rolfsii is found in destructive condition at onion growing locations in the valley districts of Manipur. The highest disease incidence was recorded in Imphal West district with maximum disease incidence being recorded from Malom. The lowest disease incidence was observed in Imphal East district with minimum disease incidence being recorded from Pukhao. The maximum disease incidence was observed during the month of April and the minimum disease incidence was observed in February in all the districts. The symptoms of white rot were not obvious during the first three months after planting. It became prominent in the month of February with yellowing of leaves followed by wilting as the disease progresses and most prominent at April when the base of onion stem starts rotting and eventually become covered with white cottony mycelial growth of the fungus in the presence of sclerotia. When such plants are uprooted, the roots, base plate, bulb scales and sometimes, the entire bulbs are decayed and watery.

\section{Introduction}

Onion (Allium cepa L.) is used both as vegetable and spice in Manipur. Both the leaves and bulb are used either raw or cooked. Onion is referred to as queen of the kitchen (Selvaraj, 1976). Onion is well known for its pungency. The pungency is due to volatile oil known as allyl propyl disulphide. Onion is rich in phenolics and flavonoids compounds that are well known to be anti-inflammatory, anti-cholesterol, ant carcinogenic, antiproliferative, and antioxidant properties (Williamson et al., 1997; Yang et al., 2004; Michael and Smith, 2005). In Manipur, onion is cultivated mostly as a cool season crop. Onion is known to suffer from various diseases and insect pests (Mishra et al., 2014). White rot of onion is one of the important diseases and it has wrecked onion cultivation in Manipur in the recent years. White rot of onion caused by Sclerotium cepivorum Berk. was first reported in Oregon in 1918 and in Virginia in 1923 and the disease was studied thoroughly in England (Walker, 1924). In Manipur, white rot of onion is caused by Sclerotium rolfsii Saccardo. The fungus is polyphagous and infects a large number of both monocotyledonous and dicotyleonous crops (Aycock, 1966; Mordue, 1974; Punja, 
1985). The fungus has a broad host range and causes southern blight on several plants. Initial stages of infection are constricted to the host root system and the fungus spread from plant to plant through root contact (Scott, 1956).

In Manipur, the detailed information about the disease is not available at present. Therefore, the research investigations were carried out to study the incidence of white rot in the valley districts of Manipur along with symptoms of the disease.

\section{Materials and Methods}

The research investigation was conducted at the Department of Plant Pathology, College of Agriculture, Central Agricultural University, Imphal during 2015-2016.

Survey for white rot disease incidence of onion at different locations in the valley districts of Manipur

Surveys were conducted during the crop season February to April in 2015-2016 for white rot of onion at different commercial onion growing locations in the valley districts of Manipur namely Imphal East, Imphal West, Thoubal and Bishnupur.

Observations on the disease incidence were taken by selecting 200 plants randomly from the farmers' field and were converted to disease incidence as follows:

$$
\text { Percent disease incidence }=\frac{\text { Total number of diseased plants }}{\text { Total number of healthy plants }} \text { X } 100
$$

Collection of the diseased samples and isolation of causal pathogen involved

The diseased bulbs were collected from surveyed areas. The infected bulb scales were cut into small pieces of $2-3 \mathrm{~mm}$ size. These pieces were surface sterilized with $1 \%$ sodium hypochloride solution. The sterilized pieces were blot dried then inoculated on potato dextrose agar medium and were incubated at $28 \pm 11^{\circ} \mathrm{C}$ for 4 days. Daily observations were taken on the development of the pathogens. The causal pathogen was purified by hyphal tip cut method and re-isolated on potato dextrose agar medium. Culture was maintained on freshly prepared potato dextrose agar medium and periodically sub cultured to fresh medium throughout the research period.

\section{Pathogenicity test of the isolated pathogen}

Pathogenicity test was done by transplanting 45 days old onion seedlings in artificially inoculated soil on plastic pots. Field soil was collected and sterilized at $15 \mathrm{lb} / \mathrm{in}^{2}$ for 2 hours consecutively for 3 days. Plastic pots were filled up with 250 grams of sterilized soil. 10 sclerotia (10 days old) were mixed with the soil and kept for 15 days. 45 days old onion seedlings were then transplanted. The seedlings were observed for typical symptoms of yellowing and wilting of leaves. Seedlings showing the characteristic symptoms were uprooted. The pathogen was re-isolated from diseased bulb scales to confirm the pathogenicity of the fungus. The pathogen was compared with relevant monographs.

\section{Detail observations of disease symptoms}

Symptoms of onion white rot were observed from seedling until maturity of the plant.

\section{Results and Discussion}

Survey for white rot disease intensity of onion at different locations in the valley districts of Manipur

White rot of onion was found well distributed at various onion growing locations in the 
valley districts of Manipur. The maximum disease incidence of 42.91, 52.42 and $65.58 \%$ was observed in Imphal West district and minimum disease incidence of $39.24,49.17$ and $59.24 \%$ in Imphal East during February, March and April respectively. The maximum disease incidence of $65.58,59.24,61.45$ and $64.09 \%$ was found in April in all the districts of Imphal West, Imphal East, Thoubal and Bishnupur respectively. The highest disease incidence was recorded in Imphal West district during the crop season from Malom during February (46.40\%), March (55.34\%) and April (67.42\%) respectively. The lowest disease incidence was observed in Imphal East district from Pukhao during February (38.38\%), March (48.12\%) and April $(56.40 \%)$ respectively. The disease incidence was less in February and March in all the districts. The disease was found to be more severe in April after the commencement of rains, therefore, indicating the influence of rainfall, higher relative humidity and lower temperature range of the soil on rapid disease development.

Table.1 Disease incidence of white rot of onion in Imphal West district of Manipur

\begin{tabular}{|l|l|l|l|l|}
\hline \multirow{2}{*}{ Name of Locality } & \multicolumn{3}{|c|}{ Percent disease incidence } & \multirow{2}{*}{ Mean } \\
\cline { 2 - 4 } & February & March & April & \\
\hline Moidangpok & 43.00 & 51.02 & 65.65 & $\mathbf{5 3 . 2 2}$ \\
\hline Malom & 46.40 & 55.34 & 67.42 & $\mathbf{5 6 . 3 8}$ \\
\hline Lamshang & 38.00 & 54.00 & 62.90 & $\mathbf{5 1 . 6 3}$ \\
\hline Kodongpokpi & 44.25 & 49.32 & 66.35 & $\mathbf{5 3 . 3 0}$ \\
\hline Mean & $\mathbf{4 2 . 9 1}$ & $\mathbf{5 2 . 4 2}$ & $\mathbf{6 5 . 5 8}$ & \\
\hline
\end{tabular}

Table.2 Disease incidence of white rot of onion in Imphal East district of Manipur

\begin{tabular}{|l|l|l|l|l|}
\hline \multirow{2}{*}{ Name of Locality } & \multicolumn{3}{|c|}{ Percent disease incidence } & \multirow{2}{*}{ Mean } \\
\cline { 2 - 4 } & February & March & April & \\
\hline Pukhao & 38.34 & 48.12 & 56.40 & $\mathbf{4 7 . 6 2}$ \\
\hline Andro & 40.62 & 49.34 & 61.16 & $\mathbf{5 0 . 3 7}$ \\
\hline Pangei & 38.00 & 51.02 & 59.20 & $\mathbf{4 9 . 4 0}$ \\
\hline Khurai & 40.00 & 48.20 & 60.20 & $\mathbf{4 9 . 4 6}$ \\
\hline Mean & $\mathbf{3 9 . 2 4}$ & $\mathbf{4 9 . 1 7}$ & $\mathbf{5 9 . 2 4}$ & \\
\hline
\end{tabular}

Table.3 Disease incidence of white rot of onion in Thoubal district of Manipur

\begin{tabular}{|l|l|l|l|l|}
\hline \multirow{2}{*}{ Name of Locality } & \multicolumn{3}{|c|}{ Percent disease incidence } & \multirow{2}{*}{ Mean } \\
\cline { 2 - 5 } & February & March & April & \\
\hline Wangjing & 40.72 & 53.00 & 62.40 & $\mathbf{5 2 . 0 4}$ \\
\hline Lilong & 39.75 & 50.32 & 59.05 & $\mathbf{4 9 . 7 0}$ \\
\hline Haoreibi & 43.00 & 50.28 & 61.00 & $\mathbf{5 1 . 4 2}$ \\
\hline Uchiwa & 43.48 & 53.35 & 63.35 & $\mathbf{5 3 . 3 9}$ \\
\hline Mean & $\mathbf{4 1 . 7 3}$ & $\mathbf{5 1 . 7 3}$ & $\mathbf{6 1 . 4 5}$ & \\
\hline
\end{tabular}


Table.4 Disease incidence of white rot of onion in Bishnupur district of Manipur

\begin{tabular}{|l|l|l|l|l|}
\hline \multirow{2}{*}{ Name of Locality } & \multicolumn{3}{|c|}{ Percent disease incidence } & \multirow{2}{*}{ Mean } \\
\cline { 2 - 5 } & February & March & April & \\
\hline Toubul khoijuman & 42.52 & 54.32 & 66.50 & $\mathbf{5 4 . 4 4}$ \\
\hline Keinou & 37.00 & 49.03 & 61.80 & $\mathbf{4 9 . 2 7}$ \\
\hline Oinam & 39.90 & 49.34 & 62.55 & $\mathbf{5 0 . 5 9}$ \\
\hline Kabowakching & 40.15 & 52.55 & 65.52 & $\mathbf{5 2 . 7 4}$ \\
\hline Mean & $\mathbf{3 9 . 8 9}$ & $\mathbf{5 1 . 3 1}$ & $\mathbf{6 4 . 0 9}$ & \\
\hline
\end{tabular}

Fig.1 Disease intensity of white rot of onion in the surveyed areas of Manipur

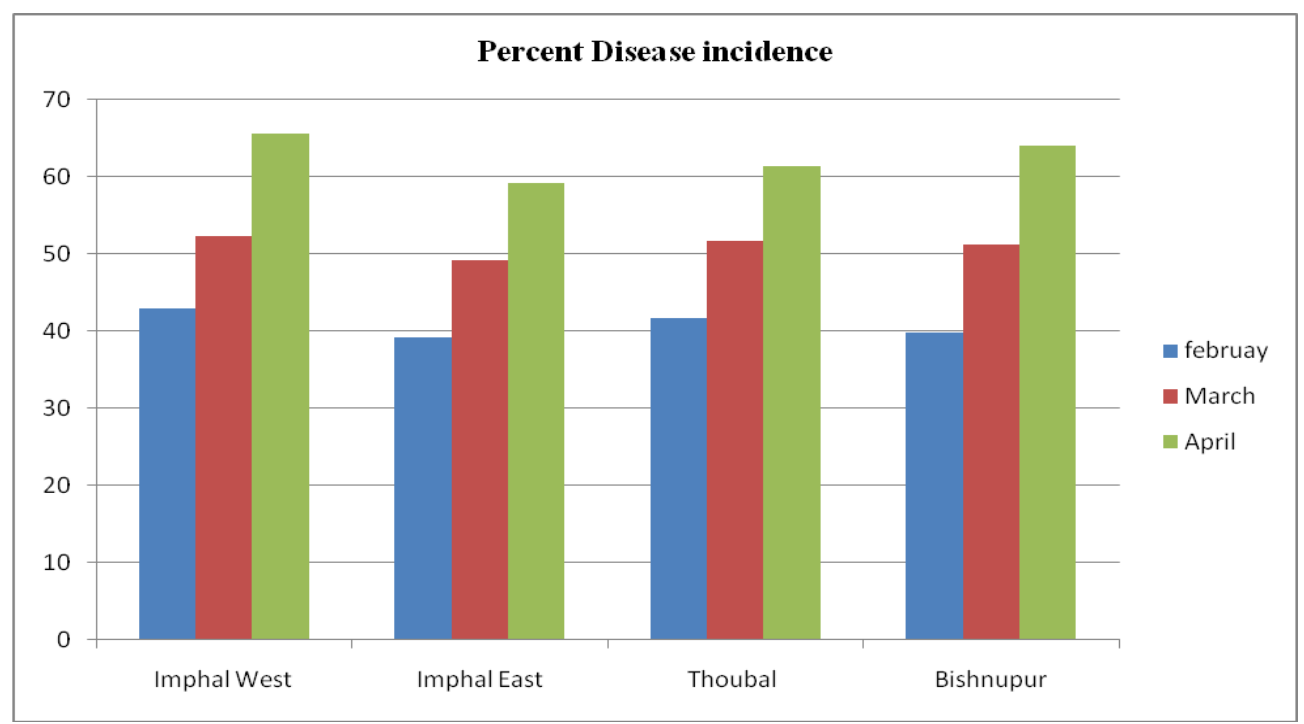

Fig.2 Sclerotium rolfsii Saccardo on potato dextrose agar

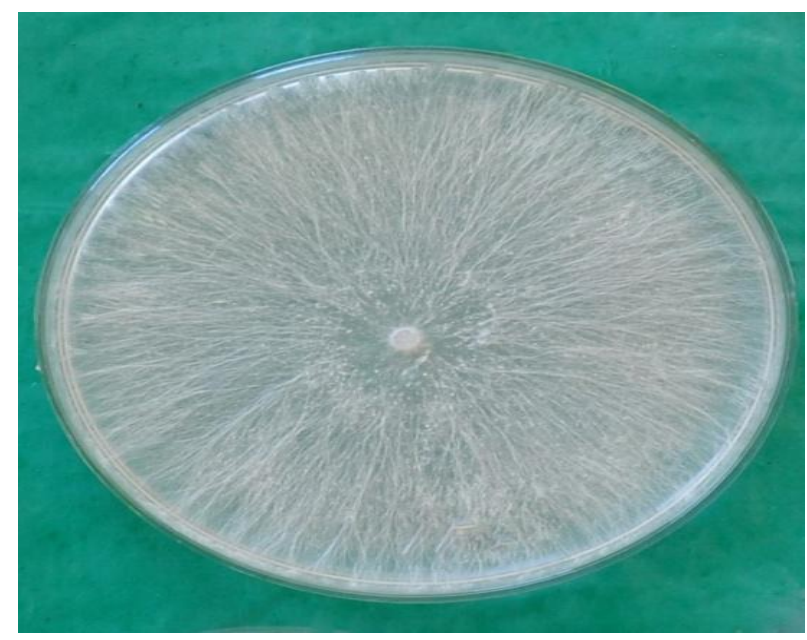


Fig.3 Development of typical symptoms on pathogenicity test
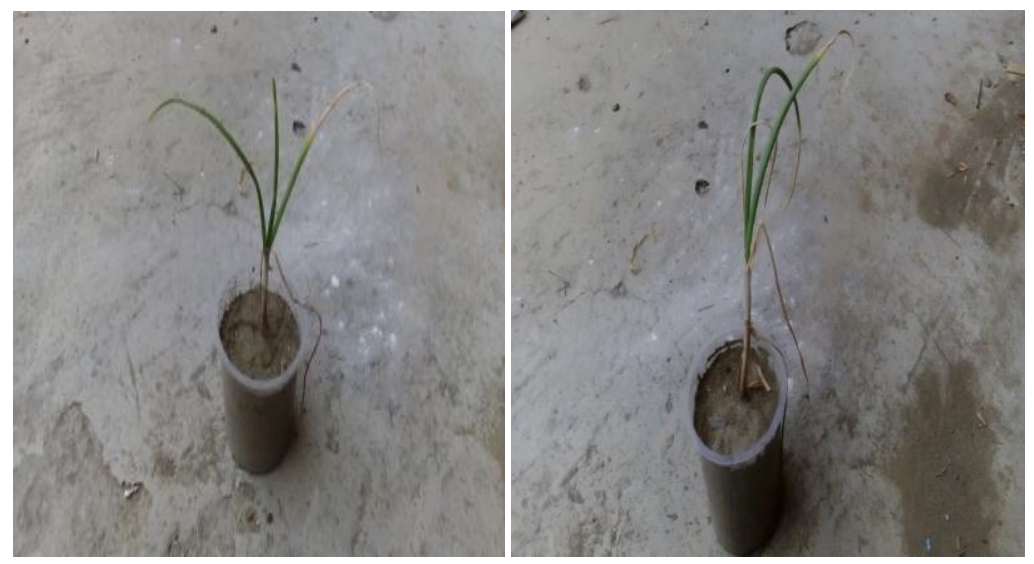

Fig.4 Infected bulb with white cottony mycelium at basal plate adjoining roots

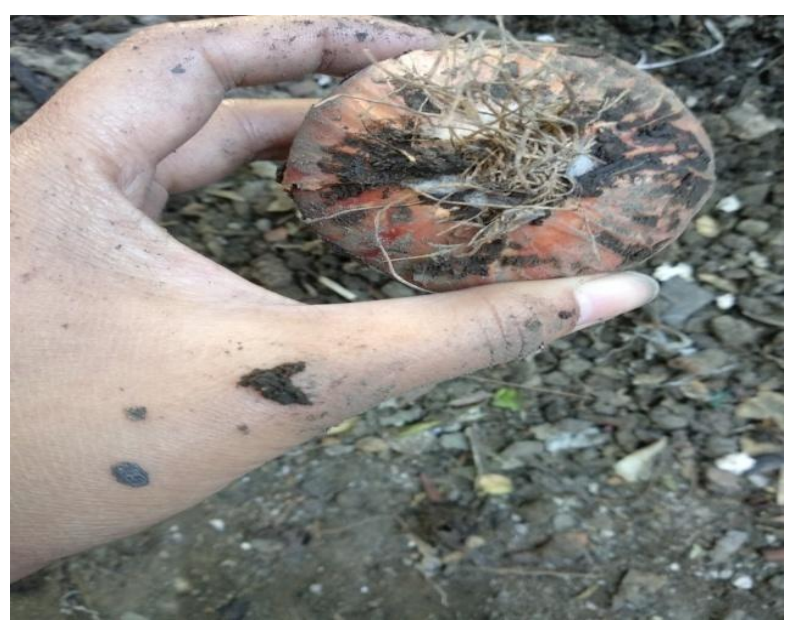

Fig.5 Yellowing and wilting of leaves

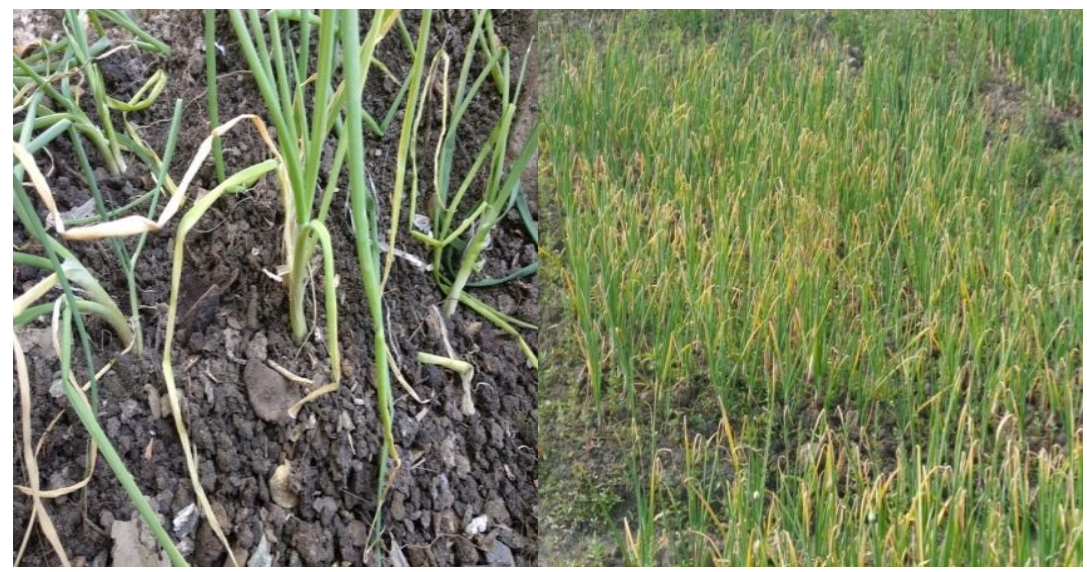


The disease progressed rapidly in April after rainfall. Walker (1924) reported that white rot of onion was most devastating in a moderately cool soil $\left(15\right.$ to $\left.18^{\circ} \mathrm{C}\right)$ having a medium moisture content after rainfall. The present findings are also in agreement with the findings of Amin et al., (2014) who reported that the disease symptoms appear from mid season to harvest and he also stated the disease to be more destructive during the early spring.

Collection of the diseased samples and isolation of causal pathogen involved

With repeated isolations of diseased samples collected from the surveyed areas, Sclerotium rolfsii Saccardo was consistently found to be associated with white rot of onion. The isolated fungus was purified and identified as Sclerotium rolfsii Saccardo on the basis of morphological characteristics and taxonomic keys available in the literature (Saccardo, 1913; Mordue, 1974).

\section{Pathogenicity test of the isolated pathogen}

The onion seedlings with characteristic disease symptoms were observed after 7 days of transplanting as colonization of inner tissues of roots and stem base occur within 57 days of inoculation (Stewart et al., 1989). The seedlings were also uprooted and exhibit characteristic symptoms of soft, watery decay accompanied by white mycelium and sclerotia. On re-isolation, the same fungus was consistently found to be associated with the disease. Hence, the pathogenicity of the fungus was proved. Mukherji and Tewari (1969) reported that Allium cepa suffered from white rot of onion caused by Sclerotium rolfsii in Lucknow. Mathur and Sharma (2002) also reported bulb rot of onion induced by Sclerotium rolfsii in Rajasthan. Kwon et al., (2011) reported Sclerotium rot of onion caused by Sclerotium rolfsii in Korea.

\section{Detail observations of disease symptoms}

The infected plants show yellowing and wilting of leaves. The tip of the leaves start drying from the tips backward, droop down and appear blighted (Walker, 1924; Kwon et al., 2011; Amin et al., 2014). At later stage of infection base of stem and leave sheath rots and collapsed (Stewart et al., 1989). The plants gradually declined and collapsed (McLean and Stewart, 2000). Bulbs are decayed, watery, soft and are covered with white cottony mycelial growth of the fungus accompanied by the presence of small, circular, white, brown and black sclerotia interspersed among the mycelial growth and infected tissues (Walker, 1924; Amin et al., 2014; Mishra et al., 2014).

During investigations, it was observed that white rot also developed on harvested onion bulbs during storage. Therefore, further research work is considered very crucial.

\section{References}

Amin, M., Shiberu, T. and Selvaraj, T. 2014. White rot (Sclerotium cepivorum Berk) - an aggressive pest of onion and garlic in Ethiopia. Journal of Agricultural Biotechnology and Sustainable Development. 6(1): 6-15.

Aycock, R. 1966. Stem rot and other diseases caused by Sclerotium rolfsii. N.C State Univ. Tech. Bull., 174: 202.

Kwon, J.H., Kim, H.D., Choi, O., Kwak, Y.S., Lee, Y.H. and Shim, H.S. 2011. Sclerotium Rot of Onion Caused by Sclerotium rolfsii. Resarch in Plant Disease 17(2): 222-224.

Mathur, K. and Sharma, S.N. 2002. Bulb rot of onion induced by Sclerotium rolfsii a new threat to onion cultivation in Rajasthan. Journal of Mycology and Pant Pathology 32(1):132-133.

McLean, K.L. and Stewart, A. 2000. Infection 
sites of Sclerotium cepivorum on onion roots. New Zealand Plant protection 53:118-121.

Michael, A.J. and Smith, B.A. 2005. Antioxidant activities of onions. Journal of Agriculture and Food Chemistry 21:345-360.

Mishra, R.K., Jaiswal, R.K., Kumar, D., Saabale, P.R. and Singh, A. 2014. Management of major diseases and insect pests of onion and garlic. Journal of Plant Breeding and Crop Science 6(11):160-170.

Mordue, J.E.M. 1974. Sclerotium rolfsii. CMI descriptions of pathogenic fungi and bacteria. No. 410. Commonwealth Mycological Institute, Kew, Surrey, England.

Mukerji, K.J. and Tewari, J.P. 1969. White rot of onion in Lucknow. PANS Pest Articles \& News Summaries 15(2):235236.

Punja, Z.K. 1985. The biology, ecology and control of Sclerotium rolfsii. Phytopathology 23: 97- 127.

Saccardo, P.A. 1913. Sclerotium rolfsii. Sylloge Fungorum XXII. Pavia, Italy. $1500 \mathrm{p}$.

\section{How to cite this article:}

Rimamay Konjengbam, Rajkumari Tombisana Devi and Naorem Iboton Singh. 2021. Disease Incidence and Symptoms of White Rot of Onion caused by Sclerotium rolfsii in Manipur. Int.J.Curr.Microbiol.App.Sci. 10(01): 478-484. doi: https://doi.org/10.20546/ijcmas.2021.1001.058
Scott, M.R. 1956. Studies of the biology of Sclerotium cepivorum Berk. II- The spread of white rot from plant to plant. Annals of Applied Biology 44:584-589.

Selvaraj, S. 1976. Onion is queen of kitchen. Kishan World 3(12): 32-34.

Stewart, A., Fullerton, R.A. and Sutherland, P.W. 1989. Infection of onion by the white rot pathogen, Sclerotium cepivorum. Journal of Phytopathology 126(1): 33-42.

Walker, J.C. 1924. White rot of Allium in Europe and America. Phytopathology 14(7): 315-322.

Williamson, G., Plumb, G.W., Uda, Y., Price, K.R., and Rhodes, M.J. 1997. Dietary quercetin glycosides: antioxidant activity and induction of the anticarcinogenic phase II marker enzyme quinone reductase in Hepalclc7 cells. Carcinogenesis 17(11):2385-2387

Yang, J., Meyers, K.J., VanDer, H.J., and Liu, R.H. 2004. Varietal Differences in phenolic content and antioxidant and antiproliferative activities of onions. Journal of Agriculture and Food Chemistry 52(22):6787-6793. 